\title{
Language Teaching Approaches in Kenyan Schools
}

\author{
Muriithi, Gerald Njuki \\ PhD Linguistics, candidate at The University of Nairobi, Kenya \\ DOI: https://dx.doi.org/10.47772/IJRISS.2021.5338
}

\begin{abstract}
The reason for conducting this research was to find out the strategies/ approaches which the teachers use in class to teach language. These strategies are the ones that play a major role in influencing the learner's performance.

The main objectives of the study, in this case, were: To come up with the approaches used in the teaching of the English language, the difficulties the teachers face when using these strategies, and to find out the influence that the teaching strategies impact on the learners' performance. Data collection was done and the target population was 300 whereby 280 were students and 20 were qualified language teachers. The criteria used to collect the data was the use of simple questionnaires, observation, and interviews among the students and the teachers. In this case of data collection, it was recorded using descriptive statistics such as pie charts and tables since they were the most efficient ways of collecting storing data for future reference, and easy retrieval when required. Data analysis was done using both quantitative and qualitative methods. The outcome was that all teachers $(50 \%)$ preferred the method of discussion which ensures every learner gets involved thus ensuring the centrality of the learner. This was in contrast were $(25 \%)$ preferred the lecture method and the others used the other methods in delivering the content as per the curriculum. This study advocates that the studentcentered approach should be adhered to as it gives the learner time to participate in class, improves the ability to recall, and influences performance. It was noticed that some teachers faced some difficulties since the number of students was a little bit large thus leading to poor choice of methods of teaching to use. In conclusion, the education stakeholders should allocate more resources to equip knowledge to the students, discussion on the method that should be used, and adding more qualified language teachers to ease the pressure the teachers face on choosing the best teaching strategy.
\end{abstract}

Keywords: Quantitative, qualitative, curriculum, descriptive statistics, data analysis

\section{INTRODUCTION}

$\mathrm{B}$ ased on this topic of study, the following will be represented. Statement of the problem, research questions, the objective of the study, rationale/justification, theoretical framework, methodology, literature review, findings, discussion on findings, and conclusions. The teaching approaches are very key in the teaching of English. This is portrayed by the way the content is presented to the students, preserved, and utilized. The use of English in Kenya based on history was declared officially when independence was attained in 1963 (the Republic of Kenya, 1964). It was to be used for the most important areas such as education and that's why it is a crucial part of academics today. English is a global language that is used in many countries for various purposes such as in academics. Therefore, it is concluded that it is an important curriculum-based subject across the world according to it is supported by (Braine, 2014).

Thus, researchers discovered learning approaches that are divided into two expository approaches and student-focused approaches. The expository approach entails well-organized teaching criteria where information is presented to the learners in a specific order. This assists in keeping the focus and attention of a learner and presents all the information one needs to know about in a way that he/she can recall. Where as the student-focused approach is where the students play a vital role in learning the basics. These strategies include group discussions, role-play, debates, and dramas. More so, English was acquired through colonization and it is being taught as a second language (Crystal, 2012). Thus, it is considered as the key curriculum subject because most of the subjects are directly related to the capability of the learner to understand the English concept and more so the aim is to get the conceptual part of it.

According to (Obanya,1999, p.19) language plays a central role in education, and without language, education is not possible. This is because it acts as a medium of expression of everything taught in class since it's an official language and most subjects are taught in it. Language is in the heart of teaching and learning since it's a medium through which new concepts and skills are got and assessed, creating social relationships and different identities are formed and increasingly deeper and more disciplinary understandings are constructed over time (Bailey, Burkett \& Freeman, 2010). In conclusion, the detailed information about the study on language teaching approaches in Kenya will be discussed in detail giving out the findings and conclusions as per the research conducted.

\section{STATEMENT OF THE PROBLEM}

English is internationally approved as an official language and more so it is an academic subject that deserves more attention than it is receiving now. And according to the Kenyan constitution (2010) article 7(3), it is well elaborated that the State shall promote diversity of languages and promote development. This airs the important part of it. It has been performed poorly by students in schools over the past and several stakeholders came in and strategies have been put in place to see this foreign and national language in Kenya being performed and higher grades being even attained in national exams. Therefore, it's a necessary subject since it's an examinable subject in schools in Kenya and considered as an official language. 
In Kenya, the overall performance of English has been wanting. This is because in the recent past the examination body (KNEC) has been giving reports showing that the language is performed poorly. The ministry of education has severally aired out concerns over poor performance by learners in English in the national exams (KNEC Report, 2006). It's considered that the reason for this poor performance is due to the state of students not taking it as a serious subject. More so, (Mwangi, 2009), says that the mother tongue is one of the challenges that influence the performance of the English language. This has resulted in big blame among the language teachers at large. Despite the value English holds, it has been blamed for low standards met and assessment has been done to find out the connection between English Curriculum and the students' performance (Indoshi, Okwara, 2009). This problem has forced the stakeholders to improve on the teaching strategies which would give language teaching a new outlook. Emphasis on these study strategies was mainly concerned with knowing the teaching strategies and the importance they had on the learners' performance.

These strategies began being implemented to the letter since the aim of the teachers was to avoid being blamed and also to ensure that the students are incapacitated with quality knowledge. The students have been talked to severally by several invited speakers who show them the impact of the language on the future of someone and the students have gained confidence and started having an optimistic view towards English.

\section{RESEARCH QUESTIONS}

i. What are the main strategies/ approaches the teacher employs employ to teach the English language in Kenya?

ii. What are the major challenges the teachers do face when applying the strategic approaches in delivering the content to the learners?

iii. What has the approaches of teaching impacted on the learners' performance in the classes mainly after accessed using the exam?

iv. What do the teachers want to be added to their present resources to ensure the English language becomes one of the most performed subjects in Kenya?

v. What is the learner's perspective based on the strategies used to deliver the content?

\section{OBJECTIVE OF THE STUDY}

i. To establish the approaches the teachers, use in the teaching of English among the learners in Kenya.

ii. To find out the major challenges the teacher faces when using these approaches when delivering the content to the learners.

iii. To know how the learners have impacted/ influenced by these strategies in their performance. iv. To be informed on what additional materials/resources the teachers want to be given to them to ensure a standard performance in English.

v. To know the learner's perspective based on the approaches used to deliver the content.

\section{RATIONALE}

As per the above, you cansee that there is a very serious concern in teaching and learning the English language in Kenya. According to (Ouma,2010), he researched the factors that lead to low performance in English and found out that this was associated with limited resources and use of mother tongue. Several groups of people have come up and are worried so much about the declining use of the language and more so its competence in compared to other countries where the language is developing. These groups include the examination councils (KNEC) and the Parents Teachers Association (PTA).At some point, the various personnel has been touring schools and the main thing that was being addressed was the declining levels of English performance. This was being addressed to the schools' heads, teachers, and the students in general.

Based on the research done by (Entwistle, 2013), shows the teaching methods do affect learners' performance. Therefore, approaches used by various teachers must be implemented to the letter since this is a basic reference where the student's performance can be gauged from. The teacher should also ensure that each learner is well-informed about the basic things he/she teaches in class. Most teachers are therefore supposed to give the learners a friendly environment and then give them motivating factors that will automatically enhance their English language leading to great performance in class.

According to (Ouma, 2010), he researched the factors that lead to low performance in English and found out that this was associated with limited resources. The government should therefore play a major role by providing enough teaching resources and also ensuring each school has enough and qualified language teachers. By making sure this is set in place the let the teachers and students play their vital role and at the end of its things will have automatically changed and the level of performance will be excellent. This will help out since at a higher learning level like universities and colleges a lot of group works and presentations of projects and assignments is normally done and good skills in languages are required to nurture the attention of the students for easy understandability.

\section{THEORETICAL FRAMEWORK}

This study has been based on the theory that supports the need that learners to take a great involvement in learning as their facilitators (teachers) give them the knowledge. An and ragogical approach places emphasis on what mostly the learner is doing and learners' knowledge and experience can be added upon by involving them in whenever case and building upon what they already know and have an interest in. 
This can be based on who defined and ragogy as the art and science of helping learners. Through this, it makes learning an easy thing since the learner is incapacitated with the basic skills of which he/she has to employ to understand the basic concepts.(McGrath,2009, P.54)shows that adults unlike children have their unique learning. According to the information brought out, the concept of teaching strategies should be well handled in the classroom thus benefiting students for quality capturing of information since some want problem-centered and others lectures.

According to Weinstein, 1983, P2learning strategies can be explained as the behaviors and thoughts which the students have and engage in which influence his/her process of encoding. Therefore, the aim of a particular strategy to be employed affects the way the learner selects, acquires, and organizes the new knowledge. Therefore, the teaching of the language includes showing the students how to learn, recall and give themselves motivation. Through the application of such methods at the end of the day, learning will be seen as an easy thing since everything entailed about language learning will be easy to remember and utilize in whatever case it is required.

The study also has been carried out to estimate the influence of both heuristic and expository strategies. This is clearly shown by the idea of (Biggs, 2011,P43) who largely support the advantage of student-centered approaches where the teacher plays an a vital role of giving out the quality content. In literature, which is part of learning English mostly demonstration is required when introducing a new concept especially in set books where the teacher has to play the central role. In conclusion, this study was not necessarily focused on the approaches of teaching but also how they impact the performance of a student in the class.

\section{METHODOLOGY}

In this part, the following are present. Research design, variables, location of study, target population, sampling techniques, sampling size, research instruments, data collection techniques, and data analysis

\subsection{Research Design}

The descriptive research design was applied since it gives accurately and systematically a description to a population. According to (Nachmias, 1981) the argument passed is that generally there are no exact necessities that are needed in conducting Case research. Therefore, research incorporated both quantitative and qualitative research design since there was a need for a deeper understanding of the areas not understood well.

\subsection{Variables}

The independent variables in this research include; the teaching methods applied, teaching resources, mode of giving directives, and the curriculum-based matters. On the other hand, academic performance in language acts as a dependent variable. Thus, the research aimed to determine the teaching strategies/approaches used.

\subsection{Location of Study}

The research study was conducted in Ngiriambu High School which is located in Naivasha Subcounty in Nakuru Kenya. The reason for choosing such a target site is because it was easy to access and it had stayed for a long time thus retrieval of first- hand information was easy.

\subsection{Target Population}

The target population was 300 in total where 280 were students and 20 English Language teachers. The teachers were the ones who gave out the information on the teaching strategies they were using and how they had influenced the performance of the students in the language.

\subsection{Sampling Techniques}

Sampling is the process of selecting the group that you will collect data from them. The main method of sampling used was purposive sampling since it was efficient in terms of cost and it does provide various types of statistical information of both qualitative and quantitative nature about something. According to research (Orodho, 2004, P1), the claim given is that purposive sampling enables a researcher to focus on the basic information-rich sources.

The school had four streams in form four where the research was mainly based. In those four streams, the 20 Language teachers assisted in the giving out of information based on the strategies they employed and the 280 and student were giving their views using questionnaires. Generally, everybody was included in carrying out the research.

\subsection{Sample Size}

The sample size consisted of 280 students and 20 language teachers making a total of 300 partakers as shown in the table below.

\begin{tabular}{|l|l|l|l|}
\hline School & $\begin{array}{l}\text { No. of } \\
\text { students }\end{array}$ & $\begin{array}{l}\text { No. of } \\
\text { teachers }\end{array}$ & Total \\
\hline $\begin{array}{l}\text { Ngiriambu } \\
\text { High } \\
\text { school }\end{array}$ & 280 & 20 & 300 \\
\hline
\end{tabular}

Figure 1 shows the sample size in Ngiriambu High school.

\subsection{Research Instruments}

This study used questionnaires, observation, and interviews. There were two questionnaires; one for the students and the other for the teachers. Both were required to fill and submit. Observations were made on the conduct of both teachers and the students in attending lessons and even the way they delivered the contents to the students and the way they used the teaching strategies to teach. In conclusion, the interview managed to be done where a selected number of 50 students were interviewed giving views on the performance in languages and the way this was aided by the teaching strategies. 


\subsection{Data Collection}

The data collection techniques used were the questionnaires, observation, and interviews which aided in the collection of both qualitative and quantitative data. The students were given questionnaires to fill under the supervision of the assistant of the researcher while the teachers were supervised by the researcher while filling them. The observation was also made which aided in knowing the strengths and weaknesses during the use of these techniques of teaching.

\subsection{Data Analysis}

The data collected from questionnaires and observation (quantitative) was recorded and it was presented in the statistical methods while the qualitative data from interviews were analyzed and major themes were recorded.

\section{LITERATURE REVIEW}

This part provides a review of the teaching approaches of language, the challenges encountered in choosing the teaching methods, and the impact on the performance of the learner.

\subsection{Language Teaching Approaches}

More the use of an approach and the suitable nature of an approach is directly related to the performance of the language in Kenya. There has been a big challenge on the usage of these approaches of teaching English in Kenya since we gained independence and formal education began to spread. Research also shows that these teaching strategies are important in the curriculum since they help in the impact of the curricular integration (Adam\& Bushman, 2006).

The teaching approach refers to the ways where a teacher decides to use a particular method to explain the content to the students so that they can understand clearly the information and implement it such that if they can be tested as they can recall. Therefore, the teacher chooses the best strategy from the two known ones like the expository where the teacher is centered and the heuristic method. In the teaching of the languages, the teacher can opt for any best strategy which can lead to good performance.

Rashid, Rahman, 2010 identified various methods in the teaching of language. These methods are Information- Base Method, Stylistic Approach method, Moral -Philosophical Method, Language-Based Method, and Personal Response Method. In the Information Based Method, we do identify the information that can lead to tactic knowledge to be grasped. On the other hand, the Stylistic Approach Method is where the teacher attempts to interpret information by looking at the language used in it. The Moral-Philosophical Method is where the student gets the moral of the information and lastly, the Language-Based Method is where the teacher encourages the students to understand vividly the language and taking part in expressing their own opinions in general.

According to (Richard,2014) the teaching of language depends on the educational philosophy, the teacher's taste, and the concept to be delivered. He points out that the teachers rarely combine both methods in teaching either in a single lesson or for several lessons in the course work. The methods used in teaching include group discussion, lecturing, and the use of student subject teachers.

\subsection{Challenges Encountered in Choosing Teaching Methods}

English is considered a second language to the students in Kenya and thus it is challenging when it comes to understanding the concept. This is an influence of different backgrounds and some ignorance by students which at the end will be put upon the teachers by the stakeholders involved and be declared that they are not offering quality teaching. This in turn affects language since the students begin to hear talks that language is difficult and they end up failing.

The research done by (Tornberg, 2000, P63)shows clearly that the main thing that determines a learner's success is attitude. Attitude refers to the settled way of doing something. It, therefore, determines the way the student perceives the language taught. According to (Csizer,2013) the argument brought out is that attitude possessed by a student

Learners experience the problem of the different styles used by the authors. You find out that the writer comes from a different cultural background and the students are supposed to be aware of the cultural norms of the author so that they can be in a position to understand the language devices used especially in poetry work (Saraceni, 2003).Therefore, students need to be taught using effective methodologies so that they can be able to understand the language used in poems and bring out the meaning. This is the reason why you find most students hate the poems since they fail to understand the figurative language in it and also the stylistic devices which create the sweetness of a poem. Thus, it has come to a belief that the students feel like poems contribute less to their language development and prefer short stories mostly.

Therefore, the option of using the best approaches to the teaching of languages should be such that students are engaged in more and ensure the method makes the students have fun and improve their attitude towards the language(Cooper, 2011). The tutor is therefore supposed to employ methods such as open class discussions which will, in turn, make the class lively since the students will be arguing out their points.

\subsection{Impact on The Performance of The Learner}

English is the most used language across the globe for different purposes but mostly the purposes that have got impacts from the study of it. Language cannot be taught in class without using the literature concept. This is because it provides a wide range of expressive examples of contextualized language. This is highly supported by (Katz, 2009) who researched this. Through learning the basics via the literature content, the student can internalize vocabulary which can improve the student's language. 
In Kenya, the education system measures the effectiveness of the teaching approaches by the use of grades scored by students in the national exams mostly. This gives out a clear indication that the teachers in class are doing something influential to the student life and the future in general. This has also helped to boost the student attitude in class and as a reference in the previous exams, there are great improvements and more speculated soon. The research was done by (Entwistle, 2013) and the outcome was that the methods strategies used in teaching greatly influence the learners' performance differently. Entwistle says that learners performed excellently when taught using problem-based methods rather than the use of traditional ones.

Sometimes language helps a learner to develop a motive skill in that he/she can make decisions based on the contextual understanding of literature materials. A student that has a positive vibe towards the study of literature is also able to understand sensitive life issues and social life awareness. It also helps a learner to develop a unique character in the society since the decision made are from the home of wise people. Through organized learning based on these strategies, the student thus acquires virtues such as love, kindness, friendship, and generosity. Robinson, 2005 declares that according to the research the learner can understand things that are of worth and the ones which are not thus influencing the decision making in life.

In conclusion, the study of English has brought many students a wide understanding of the new arguments based on literature and has given them great exposure to meaningful contexts and fascinating characters whom, they try to emulate in a real-life situation. Also, literature has led to the exposure of new vocabularies which improve the language to a different level which in turn makes learning enjoyable (Khatib, 2011). Through this, the students develop that state of exploring an imaginary world and come up with values that do represent the voice of a community with people that can lead and also offer guidance based on the capacity of their knowledge.

\section{FINDINGS}

The study was mainly concerned with the study on teaching strategies that are used in Kenya as the main objective. The research was conducted in Ngiriambu High school in Naivasha Sub-County in Nakuru County. The findings are as follows:

\subsection{Teaching Methods Used To Teach Language}

According to the report, the student-centered approach was the one commonly used which is under the heuristic approach. In this case, the students are involved in group discussions, dramatization, role-plays, and debates. This came to vividly show that the classes were lively since at times it ensured every student air their opinions and thus making the class lively. Some teachers used the lecture method which is under teacher- based strategy. In this method, the students are used as vessels where the content is delivered by the teachers and places the student into. position of making moral judgment and grasp the content. According to the research by (Braine, 2014), the argument brought out is that the learners learning should be assessed through tests and see what they score. This is shown clearly by the figure below based on the information the teachers gave from the filled questionnaires.

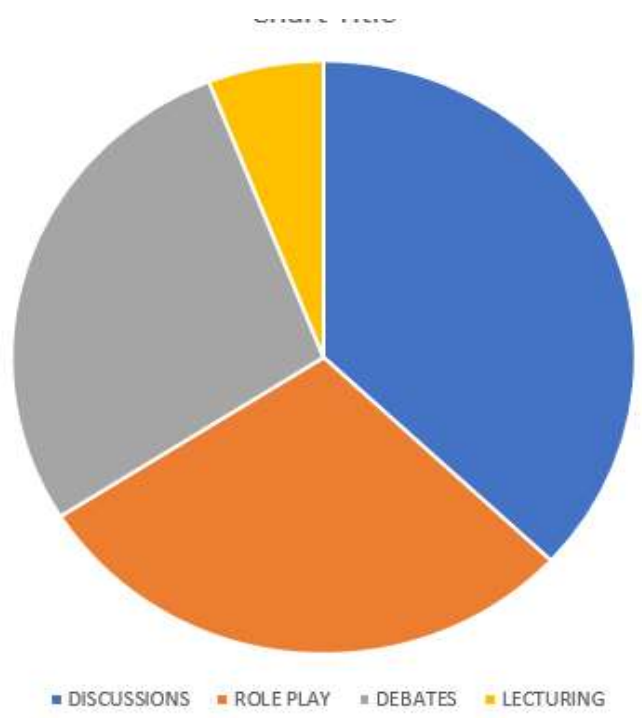

Figure 2 shows the language teaching methods.

According to the research, figure 2 shows how the teaching methods were being used, and it can be seen clearly that discussions were the leading strategy since it was the most preferred method in that environment. The other methods such as role-plays, debates, and lecturing follow consecutively since they represent a certain percentage of importance in the study of language.

\subsection{Lesson Attendance and Time Management}

According to the research, the information and the conduct of teachers were really good since the time was managed properly by both students and teacher. Even the lessons were being followed strictly and the content was delivered well in the minimum allocated time. Most of the students were punctual and ready to learn the language since the methods the teachers used made the classes lively. The teachers were also organized and knew what they were going to teach the students. One of the feedbacks from the students was that the English language was really interesting especially in the literature part and thus the conclusion made was that the teachers used their time well to deliver.

\subsection{Sufficiency of Learning Materials}

The observation made was that there are not more physical resources that facilitate the teaching of the English language but the teachers did struggle to search for materials online which had a great impact on the learners and thus it was a clear indication that the results would be perfect at some point. The textbooks were not that enough for reference but they had been promised by the Government that the issue would be solved. This was widely discussed from the 
questionnaire given and the following figure shows the percentage distribution of resources available for learning.

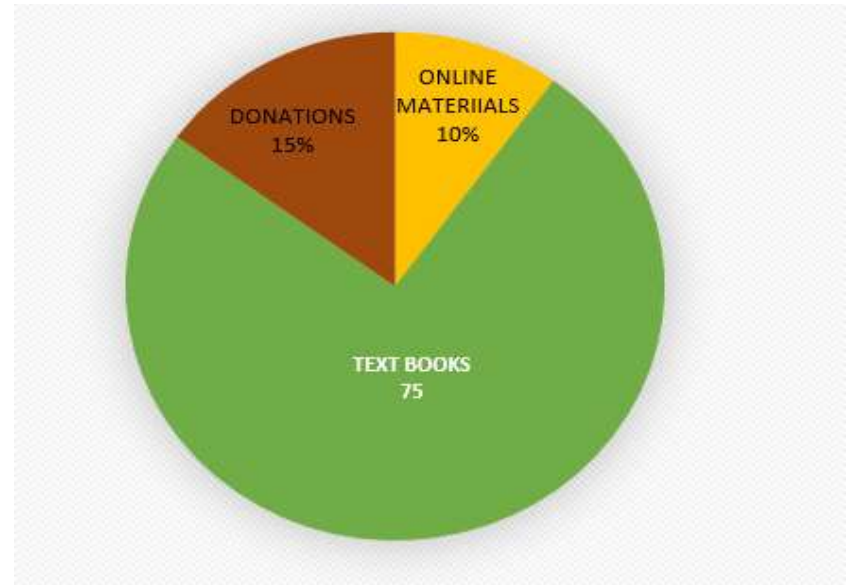

Figure 3 shows the allocation of learning materials

In Ngiriambu High school learning has been mainly supported by the use of textbooks issued by the government. This is seen from figure 3 where textbooks take the highest percentage. Donations and online materials were also assisting in learning but with a small percentage of use.

\subsection{Impact of the Teaching Strategies on the Learners}

The main objective was to find out how these strategies had a big impact on the learners' performance. After giving out a questionnaire to the students, the responses were both positive and negative since most of the students claimed that the resources were less which in turn led to slightly poor performance in the language. Others did claim that the teachers were not enough and the issue was being worked on by the education sector in the county to supply more teachers. The performance has not been that bad since the students do try to improve in every exam since there is always an increase in overall grade and points. The following graph shows the overall improvement in language performance.

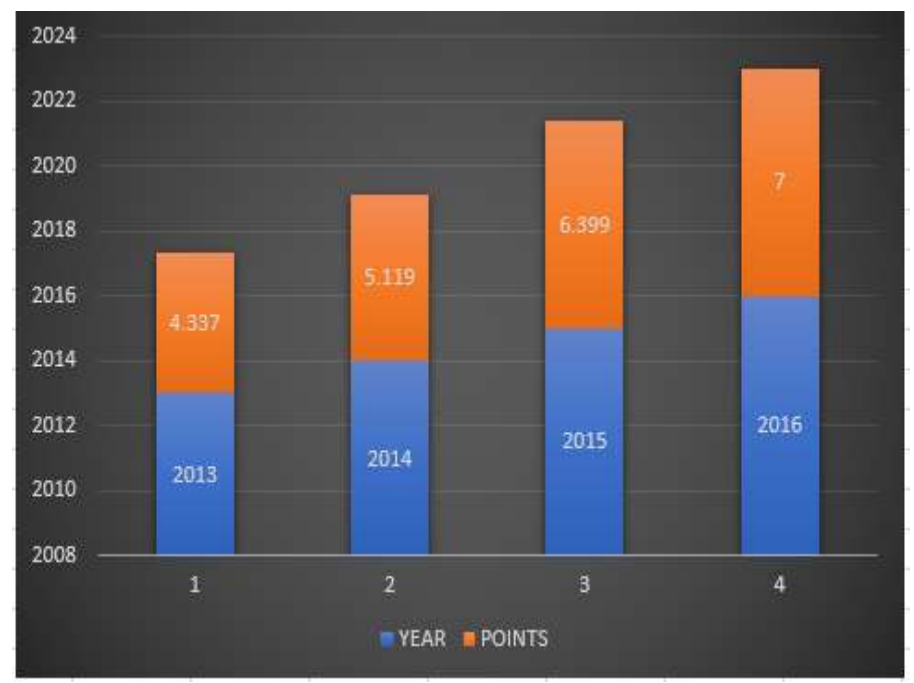

Figure 4 shows the impact of learning strategies on students' performance
According to figure 4, the learners' performance has been highly influenced since there is a significant increment in the overall points every year. Therefore, it can be concluded that the teaching approaches have done a great job in gauging the students' performance.

\section{DISCUSSION ON THE FINDINGS}

According to the research, various findings were made in the school, and discussions on the findings are as below.

Firstly, based on the strategies used in the school for teaching the student-centered and teacher-centered methods are mainly applied. Student-centered is the one that has got many teachers using it and sometimes the teacher-centered which is rare. In the learner-centered approach which is under the heuristic strategy the following are applied in teaching. Use of student leaders, group discussions, dramatization, and roleplaying. The teachers in the school have been applying such to improve on the language. Also, there is the method of teachercentered where the main thing don is lecturing where the teacher feeds the students the content without involving the students like in the other method. In conclusion, the learnercentered method plays a major role. Moreso, according to the research and observation being considered most, it was seen that the discussion method was the most applied strategy of teaching compared to others. This is because it has impacted positively on the learners' performance, it was lively and every student could be involved, and based on the available resources it was the best in incorporating knowledge.

Secondly, the time management in the school is observed to the letter since everything in the school is run under strict directions from the heads thus ensuring the smooth running of the process of imparting knowledge. The students are well managed and self-driven in class and also very punctual in doing all the necessities they are required. This has tried to improve on the performance since the students have enough time to read and even be taught.

Thirdly, the availability of enough resources for learning has been a major problem but the teachers are trying to have alternative sources which include online materials which they use to teach and even give out assignments on the languages. The reference books are not enough which implies that the sharing ratio is not maintained. The government is through various stakeholders is trying to come up with ways to ensure sufficient resources in general to boost the performance.

In conclusion, the teaching strategies have influenced the learners' progress in performance. Day- in day- out the results keep changing because the teachers have tried their best to impart knowledge and the sweetest part of it is that good grades are seen and there is aclear indication that there is still more to come. Thus, the students are happy there is a clear improvement based on these methods of learning. 


\section{CONCLUSION}

From the discussion of the findings, it can be concluded that the teaching strategies used by the teachers in Ngiriambuhigh school have helped to improve performance in the day-to-day learning business. The use of both learner-centered and teacher-centered methods has done a great job in imparting knowledge to the students. In a large voice from the language teachers, the learner-centered method was the one preferred since its fruits had been seen for a series of several years, and thus there were no many complaints.

The study concluded that lack of sufficient learning facilities made sometimes the teachers use teacher-centered -strategy. This was given out by several teachers who said that lack of enough learning materials made them use that method at times. This was seen as a hindrance and hectic sometimes on both sides of the students and the teachers.

Another thing that was observed that whenever a study was done in class and assignments given to the students, individual performance was seen to be poor compared to that of the group. Therefore, a conclusion was made that the students had adopted the learner-centered method which was easy and made the lass lively since everyone could participate. This gave room for none learning his own mistakes and by looking at others' work he/she would rectify.

Lastly, most of the students had developed a positive attitude toward learning. This would be seen according to the way they performed in language. Also, the students themselves were proud of themselves since everything was set in place and thankful to their teachers who went even beyond the level of the available resources. Thus, these approaches had done a great thing since the performance was good and it was quite improving from one academic year to the other. In, general the learner-base strategy has done a great thing in imparting knowledge.

\section{REFERENCES}

[1] Bailey, F. Burkett, B \& Freeman, D (2010). The mediating role of language in teaching and learning. A classroom perspective.

[2] Biggs, J. B. (2011). Teaching for quality learning at university: What the student does. McGraw-Hill Education (UK).

[3] Adams, J. \& Bushman, J. (2006). Thematic solution using young adult literature to increase reading comprehension. Middle School Journals, 37(4), 25-29

[4] Braine, G. (Ed.). (2014). Teaching English to the world: History, curriculum, and practice. Routledge.

[5] Cooper, J. E. (2011). Toward a conceptual framework of culturally relevant pedagogy: An overview of the conceptual and theoretical literature. Teacher Education Quarterly, 65-84.

[6] Crystal, D. (2012). English as a global language. Cambridge University Press.
[7] Scissor, C. M. (2013). Consumer Protection-Institutionalization and Public Judgement.

[8] Entwistle, N. J. (2013). Styles of learning and teaching: An integrated outline of educational psychology for students, teachers, and lecturers. Routledge

[9] Indoshi, Okwara F. C. (2009). Towards a model of integrated English language curriculum for secondary schools in Kenya. Educational Research and Reviews, 4(5), 301-309.

[10] Katz, S. (200). Teaching Students with Reading Difficulties to be Close: Feasibility Study (ERIC Document Reproduction Service No. ED481417).

[11] Khatib, M. (2011). Why \& Why Not Literature: A Task-Based Approach to Teaching Literature. International Journal of English Linguistics, Vol. 1., No. 1.

[12] Kenya National Examination Council (KNEC Report 2006).

[13] Kenyan Law Reports (2010). Constitution of Kenya 2010. National Council for Law Reporting.

[14] McGrath, V. (2009). Reviewing the Evidence on How Adult Students Learn: An Examination of Knowles' Model of Andragogy. Adult Learner: The Irish Journal of Adult and Community Education, 99, 110.

[15] Ministry of Education (2012). The use \& performance of language in primary \& secondary schools in Kenya. Nairobi: Government Printer.

[16] Mwangi, L. B. (2009). Factors influencing students' performance of English language in Kenya certificate of secondary examination in secondary schools in Meru-North District, Kenya. Nairobi: University of Nairobi.

[17] Nachmias, C., \& Nachmias, D., (1981). Research Methods in the Social Sciences. London: Edward Arnhold

[18] Obanya, P. (1999). Education, equity, and transformation from the perspectives of language education. Comparative Perspectives on Language and Literacy. Dakar: UNESCO West Africa Regional Office, 17-30.

[19] Orodho, A. J. (2004). Essential of Education and Social Science Research Methods. Masola Publisher.

[20] Ouma, K. (2010). Factors affecting performance in Kenya Certificate of Secondary Education (K.C.S.E) English Examinations in Nyamache Division, Gucha District, Kenya. Nairobi: Kenyatta University Press.

[21] Republic of Kenya (1964). Report of Kenya Education Commission. Nairobi: Government Printer.

[22] Rashid, U. et al. (2010). Research Methods for Business. A Skill Building Approach, 4th Edition. Carbondale: John Wiley and Sons.

[23] Republic of Kenya (1964). Report of Kenya Education Commission. Nairobi: Government Printer.

[24] Richards, J. C., \& Rodgers, T. S. (2014). Approaches and methods in language teaching. Cambridge University Press

[25] Robinson, J. (2005). Deeper Than Reason: Emotion and Its Role in Literature, Music, and Art. Clarendon

[26] Saraceni, M. (2003). Literature in the EFL Classroom: Roses or Thorn? In Gran Akuma

[27] Tornberg, U. (2000). Om språkundervisning i mellanrummet-och talet om" kommunikation" och" kultur" $i$ kursplaner och läromedel från 1962 till 2000 (Doctoral dissertation, Acta Universitatis Upsaliensis).

[28] Weinstein, Claire, Mayer Richard E. (1983). The Teaching of Learning Strategies. 


\section{APPENDICES}

\section{Appendix I: Questionnaire for an English Language Teacher.}

\section{Instructions:}

Kindly read the questions below and answer by ticking the choice you find suitable or fill in the blank spaces. Information provided will only be used for the study. Please do not write your name.

1. What is the level of education reached?

i. Diploma []

ii. Degree []

iii. Masters [ ]

iv. Any other.......

2. How long have you taught Language in school approximately?

i. Below 5 years [ ]

ii. 5-15 years [ ]

iii. $\quad 15$ and above [ ]

3. How many Language lessons do you have in a week?

i. $\quad 8-14$

ii. $\quad 15-19$

iii. $\quad 20-25$

4. Where do you fetch additional learning materials?

i. Online

ii. Borrowing

iii. Ignoring

5. Approximately how many students do you teach in a class?

i. $\quad 50-100$

ii. $\quad 101-150$

iii. $\quad 151-200$

6. In your perspective has the use of the strategies in learning increased or decreased the performing rate of students? (YES)or (NO)

If yes, briefly

explain

7. How often do you use these strategies of teaching the English language in class?

i. Always
ii. Sometimes
iii If I feel like.

8. Which of the following strategies do you prefer while teaching language?

Discussion [ ]

Lecture [ ]

Debates [ ]

Dramatization [ ]

Role play [ ]

Others [ ] 
9. How have these strategies impacted the performance of the students?

i. Excellent [ ]

ii. Median [ ]

iii. Poor [ ]

10. Suggest atleast four ways of improving language performance.

i.

ii.

iii.

iv.

V.

\section{Appendix II: Questions for English Language Student}

Instructions: Kindly read the questions below and answer by ticking the choice you find suitable or fill in the blank spaces. Information provided will only be used for the study. Please do not write your name.

1. Gender.

Male [ ] $\quad$ Female[ ]

2. Age

i. $\quad 13-17$

ii. $\quad 17-20$

iii. $\quad$ More than 20

3. Give atleast four challenges experienced when learning the English Language

i.

ii.

iii.

iv.

V.

4. Which reasons do you think have led to poor performance in the English Language in your school?

i. $\quad$ Large class size

ii. Insufficient learning and teaching materials.

iii. $\quad$ Poor teaching methods applied

[]

iv. Lack of support from the Ministry of Education

v. Others, Specify

5. Give ways of improving on performance.

i.

ii.

iii.

iv.

6. Where do you fetch additional reference materials?

i. Online [ ]

ii. Borrowing [ ]

iii. Using the available ones [ ]

7. According to the way you do perform where can you range yourself?

i. Excellent [ ]

ii. Good [ ]

iii. Hardworking [ ]

8. How have the strategies improved your level of English?

i. Highly-improved [ ] 
ii. Median improved [ ]

iii. Struggling level [ ]

9. How many times do you read literature in a week?

i. Several [ ]

ii. Sometimes [ ]

iii. Rarely [ ]

10. What is your target grade in the National examination?

i. $\mathrm{A}[\mathrm{]}$

ii. $\mathrm{B}[\mathrm{]}$

iii. $\quad \mathrm{C}[\mathrm{]}$

iv. $\mathrm{D}[\mathrm{]}$

v. E[ ] 